\title{
RELATIONSHIP OF RESISTANCE-RELATED ENZYME ACTIVITY AND SALICYLIC ACID CONTENT IN PHALAENOPSIS SPECIES WITH DIFFERENT LEVELS OF RESISTANCE TO DICKEYA DADANTII
}

\author{
I Putu Wahyu SANJAYA ${ }^{1}$, Dewi SUKMA ${ }^{2 *}$, Sudarsono SUDARSONO ${ }^{2}$, Ming-Tsair CHAN ${ }^{3}$ \\ ${ }^{1}$ Plant Breeding and Biotechnology Study Program, Graduate School, IPB University, Indonesia \\ ${ }^{2}$ Department of Agronomy and Horticulture, Faculty of Agriculture, IPB University, Indonesia \\ ${ }^{3}$ Academia Sinica, Biotechnology Center in Southern Taiwan, Taiwan
}

Received: July 2021; Accepted: November 2021

\begin{abstract}
Orchids (Phalaenopsis) are ornamental plants that are cultivated commercially and in great demand in the market. Soft-rot disease (SRD) caused by the necrotrophic pathogen Dickeya dadantii is a cause of considerable economic loss to cultivators of many orchid species. Our previous experiment identified a limited number of species that were resistant to $D$. dadantii. This study aimed to validate the resistance level of four Phalaenopsis species in a detached leaf inoculation protocol to identify the resistance mechanism(s) involved. Soft-rot symptom diameter was measured from 6 to 18 hours post-inoculation (HPI) with $D$. dadantii. Disease assessment confirmed that $P$. amboinensis is a resistant species, $P$. pantherina is a susceptible species, and $P$. amabilis and $P$. schilleriana are very susceptible species. There was no difference in the lignin content between the resistant and very susceptible species. Detailed observation of resistant and very susceptible species, $P$. amboinensis vs. P. amabilis, revealed higher phenylalanine ammonia-lyase (PAL) and peroxidase (POD) in $P$. amabilis than in $P$. amboinensis. In contrast, there was higher salicylic acid (SA) content in $P$. amboinensis than in $P$. amabilis. These results suggest that POD and PAL activities may not be effective in defense against soft-rot disease, while SA plays an important role in the resistance of $P$. amboinensis to $D$. dadantii. Low PAL activity in $P$. amboinensis implies that the SA contents from the isochorismate pathway may be involved in the mechanism of $P$. amboinensis resistance to $D$. dadantii. Therefore, endogenous SA content may be a good indicator for screening resistant species in Phalaenopsis.
\end{abstract}

Key words: necrotrophic, orchid, phenylalanine ammonia-lyase, peroxidase, salicylic acid, soft-rot disease

\section{INTRODUCTION}

Plant-pathogen interaction can be diverse depending on the nature of the pathogens. Briefly, biotrophic plant pathogens stay inside living host tissues in a long-term feeding relationship. In contrast, necrotrophic pathogens are parasitic organisms that kill the living cells of their host and then feed on the dead matter. Hemibiotrophic pathogens have a biotrophic phase as the initial stage of infection and switch to the necrotrophic in the last steps of the disease or pathogen life cycle (Göhre \& Robatzek 2008; Davidsson et al. 2013; Fatima \& Senthil-Kumar 2015; Potrykus et al. 2018; Huang et al. 2020).
Soft-rot disease (SRD) caused by a necrotrophic pathogen is an obstacle to Phalaenopsis production. SRD caused up to $75 \%$ Phalaenopsis plant loss in Ridho Nurseries in West Java (Hanudin \& Suhardi 2009). According to molecular identification, the pathogen causing SRD in Phalaenopsis is Dickeya dadantii (Sudarsono et al. 2018). Rotting, wet, and foul smells may be emitted from the SRD-infected tissue in Phalaenopsis. The disease spreads asymptomatically on the plant surface, pots, tools, irrigation water, soil, and many surfaces around the cultivating areas and can survive for several months (Pérombelon 1992; Czajkowski et al. 2011). The SRD pathogen needs an entry point into the plants to successfully infect them. 
Natural openings such as stomata and physical wounds on the plant surface, along with plant maintenance, repotting, or distribution, may facilitate the pathogen entrance.

Most Phalaenopsis species, including P. amabilis, are susceptible to SRD, but two prospective resistant species (P.amboinensis and P. pantherina) were reported by Sukma et al. (2017). The susceptibility of $P$. amabilis was also reported by Sanjaya et al. (2020) and Lubis et al. (2020). The availability of the resistant species is essential in the resistance breeding program, and the study of resistance mechanisms is necessary for further use in a typical or molecular breeding. Our preliminary investigations did not find differences in leaf water content or leaf thickness, but we found a difference in stomata density between some Phalaenopsis species. However, there was no correlation between stomatal density and the SRD severity. We predicted that the leaf characteristics that we observed might not be involved in the Phalaenopsis resistance to SRD. We postulated that observing the initial response post-pathogen infections would give us insight into the plant defense of resistant Phalaenopsis species to SRD.

Constitutive features influence the plant response to biotic and abiotic stresses and modify plants' defense mechanisms. The defense mechanisms are of a physical and biochemical nature (Mithöfer \& Maffei 2017). They act in a constitutive or induced manner. Most of the physical defenses such as cell walls, waxy epidermal cuticles, and bark protect the plant as barriers that keep out infection and give strength and rigidity. The biochemical defenses are commonly induced after the plant detects the pathogen infections and response (Freeman \& Beattie 2009). However, there are also some induced physical defenses such as callose deposition and lignification (Bhuiyan et al. 2009; Luna et al. 2011; Wang et al. 2021) and constitutive biochemical defenses known as phytoanticipins (various antimicrobial and repellents) (Pedras \& Yaya 2015).

Induced defense is activated when the host plant recognizes the presence of the pathogen, which leads to the molecular and biochemical cascades as a response. ROS, as the earliest response (including hydrogen peroxide, $\mathrm{H}_{2} \mathrm{O}_{2}$ ) after the perception of pathogen-associated molecular patterns (PAMPs), has been reported in many plants (Bolwell \& Wojtaszek 1997; Bindschedler et al. 2006; Gill \& Tuteja 2010; Wang et al. 2020).
At a low level, ROS is essential in cellular proliferation and differentiation (Mittler 2017). Under biotic or abiotic stress, plants generate many ROS involved in the regulation of pathogen defense, programmed cell death (PCD), and stomatal behavior (Gill \& Tuteja 2010; Schippers et al. 2016). High ROS accumulation is often referred to as oxidative bursts (Singh et al. 2021) that are toxic to both of host and the pathogen. To deal with the high ROS level, the host plant produces enzymatic and non-enzymatic antioxidants (Hasanuzzaman et al. 2020) as the ROS scavenger that works synergistically and interactively to neutralize free radicals (Huang et al. 2019). Enzymatic antioxidants mainly include superoxide dismutase (SOD), catalase (CAT), and peroxidase (POD), while the non-enzymes antioxidant includes glutathione, ascorbic acid (AsA), and flavonoids (Gechev et al. 2006; Huang et al. 2019; Kapoor et al. 2019).

POD is one of the ROS scavengers that convert toxic hydrogen peroxide to water and oxygen (Giorgio et al. 2007). POD activities indicate signal transduction to the remote sites, resulting in necrosis and cell death (Simons \& Ross 1971). PAL is an essential enzyme in the phenylpropanoid biosynthesis pathway, producing non-enzymatic antioxidants like flavonoids and salicylic acid (SA) (Zhang \& Liu 2015; Lefevere et al. 2020). SA, jasmonic acid (JA), and ethylene (ET) are well-known biochemical compounds that act as signal transducers in the plant to induce defense response genes (Andersen et al. 2018). Both POD and PAL are involved in early resistance response in plants. High POD and PAL activities were found in infected resistant barley seedling, cotton, and Hibiscus trionum compared to control or susceptible genotypes to Verticillium dahliae (Walters et al. 2002; Golubenko et al. 2007; Xu et al. 2011). High PPO and POD activities were also observed in resistant potato genotype derived through somatic hybridization compared to the Polish cultivar susceptible to Erwinia carotovora (Łojkowska \& Hołubowska 1992).

Analysis of biochemical components as POD and PAL in Phalaenopsis response is expected to help in understanding mechanisms of Phalaenopsis resistance to $D$. dadantii and, if they are related with resistance, to validate the resistance level of Phalaenopsis species. In this study, we intend to validate the resistance level, POD, and PAL activities of four Phalaenopsis species and analyze POD, PAL, and SA performance in resistant versus very susceptible species to $D$. dadantii infection. 


\section{MATERIALS AND METHODS}

\section{Plant materials}

Four Phalaenopsis species, namely P. amboinensis, $P$. pantherina, $P$. schilleriana, and $P$. amabilis, were collected from nurseries in West Java. The plants of each species were adapted to experimental conditions in a plastic, shading net house under $50-80 \%$ relative humidity, at $27-30{ }^{\circ} \mathrm{C}$, with $80 \%$ shading. Fertilizers and vitamin B1 were applied twice a week, while fungicides, acaricides, and pesticides twice a month for three months.

\section{Plant inoculation with $D$. dadantii}

D. dadantii isolate was obtained from Plant Molecular Biology Laboratory (PMB Lab), Department of Agronomy and Horticulture, Faculty of Agriculture, Bogor Agricultural University. The isolate was previously confirmed as pathogenic to Phalaenopsis (Lubis et al. 2020; Sanjaya et al. 2020; Putri et al. 2021). Isolate preparation was made, according to Sanjaya et al. (2020). Briefly, a single colony of D. dadantii was cultured in $15 \mathrm{~mL}$ of lactose broth medium and shaken (100 rpm) overnight at room temperature. The culture was then centrifuged at $8,000 \mathrm{rpm}$ for 6 minutes. The pellet was diluted with sterilized water to the concentration $\mathrm{OD}_{600}=0.2$. The inoculation was performed using detached leaves following Putri et al. (2021) protocol. The leaf of each plant was cut into $2 \mathrm{~cm}$ long parts. The abaxial sites were gently pricked using a sterilized needle. The wound was dropped with $10 \mu \mathrm{L}$ of $D$. dadantii culture (inoculum concentration $6 \times 10^{6} \mathrm{CFU}$ ). The leaf cuts were then incubated in covered plastic boxes lined with wet tissue paper at the humidity of $75 \%$.

\section{Disease assessment}

Diameters of rot lesions (SrSD) on inoculated leaves were measured every six hours until 18 hours post-inoculation (HPI) using an automatic caliper. The results were scored on the scale from 0 to 10 :

0 (no symptoms);

$1(0.1-1 \mathrm{~mm})$;

$2(1.1-2 \mathrm{~mm})$;

$3(2.1-3 \mathrm{~mm})$;

$4(3.1-4 \mathrm{~mm})$;

$5(4.1-5 \mathrm{~mm})$;

$6(5.1-6 \mathrm{~mm})$

$7(6.1-7 \mathrm{~mm})$;

$8(7.1-8 \mathrm{~mm})$;

$9(8.1-9 \mathrm{~mm})$;

$10(>9 \mathrm{~mm})$.
Symptom scoring was used to calculate the disease severity (DS) following the formula by Sanjaya et al. (2020):

$$
\text { DS }(\%)=\frac{\Sigma(\mathrm{ni} \times \mathrm{vi})}{\mathrm{Z} \times \mathrm{N}} \times 100 \%(1),
$$

ni - $0,1,2,3,4,5,6,7,8,9$, and 10;

$\mathrm{vi}$ - disease score in the score of I;

$\mathrm{Z}$ - maximum score value;

$\mathrm{N}$ - number of samples observed.

The plant resistance level to $D$. dadantii was classified based on DS value:

DS of 0-20\% - resistant (R);

DS of $21-40 \%$ - moderate resistant (MR);

DS of 41-60\% - moderate susceptible (MS);

DS of $61-80 \%$ - susceptible (S);

DS of $>80 \%$ - very susceptible (VS).

Colony-forming units (CFU) from infected leaves were observed at 18 hours post-inoculation. The $50 \mathrm{mg}$ leaf samples were taken from the area around the soft-rot symptom. The samples from three infected leaves from each species were mixed and ground together in $1 \mathrm{~mL}$ of sterile distilled water. The suspensions were diluted into seven serial dilutions. Each dilution ( $3 \mu \mathrm{L})$ was dropped into NA medium, incubated at room temperature overnight, and the growing colonies were counted and normalized as CFU per mg following the formula: infected leaf sample $\left(\mathrm{CFU} \cdot \mathrm{mg}^{-1}\right)=$

$$
\frac{\text { number of colonies }}{3 \mu \mathrm{l}} \times \frac{1000 \mu \mathrm{l}}{50 \mathrm{mg}} \times \text { dilution factor (2). }
$$

The area under the disease progress curve (AUDPC) was calculated by using the formula below:

$$
\text { AUDPC }=
$$

$\sum \frac{\text { symptom diameter difference }}{2} \times$ observation time interval (3).

\section{POD, PAL, SA, and lignin content in resistant} $P$. amboinensis and very susceptible $P$. amabilis species

To evaluate the relationship between POD and PAL activities with resistance ability, we performed quick screening for these four species (P.amboinensis, P. pantherina, P. schilleriana, and P. amabilis). Three leaf samples from three biological repeats of each species were inoculated with $D$. dadantii (inoculum concentration of $3 \times 10^{6} \mathrm{CFU}$ ) and taken for protein extraction at 12 and 16 HPI. Three leaves of each species were mixed into one sample for protein extraction and then used to quickly screen PAL and POD activities. 
To confirm the defense mechanism, we choose two species with a distinct resistance to $D$. dadantii to perform POD and PAL activities and SA contents. This step used four biological repeats for each species inoculated by $D$. dadantii with detached leaf inoculation methods (inoculum concentration of $6 \times 106 \mathrm{CFU}$ ) and compared them to non-inoculated leaves (mock inoculation) using sterile distilled water. Leaf samples from inoculated and non-inoculated plants were taken at $12 \mathrm{HPI}$ and ground for protein extraction.

Proteins were extracted following the protocol by Sukma et al. (2012). The $0.5 \mathrm{~g}$ of leaf tissue was ground in cold phosphate buffer $(50 \mathrm{mM}, \mathrm{pH} 7)$ at a $1: 4(\mathrm{w}: \mathrm{v})$ ratio and centrifuged at 5,000 rpm and $4{ }^{\circ} \mathrm{C}$ for 10 minutes. The supernatant was then taken, and total dissolved protein was determined using the protocol outlined in Lowry et al. (1951). Buffer A $\left(0.9 \mathrm{~mL}, 2 \% \mathrm{Na}_{2} \mathrm{CO}_{3}\right.$ in $100 \mathrm{~mL}$ of $\left.1 \mathrm{~N} \mathrm{NaOH}\right)$ was added to $1 \mathrm{~mL}$ of protein and homogenized by vortex, and then incubated at $50{ }^{\circ} \mathrm{C}$ for 10 minutes. The $0.1 \mathrm{~mL}$ of buffer B $\left(0.5 \% \mathrm{CuSO}_{4} \cdot 5 \mathrm{H}_{2} \mathrm{O}\right.$ in $100 \mathrm{~mL}$ of $1 \% \mathrm{Na}_{2}$ Tartrate $2 \mathrm{H}_{2} \mathrm{O}$ ) was added to the solution, followed by homogenization, and incubated at room temperature for 10 minutes. Then $1 \mathrm{~mL}$ of buffer $\mathrm{C}$ ( $50 \mathrm{~mL}$ of buffer $\mathrm{A}+1 \mathrm{~mL}$ of buffer B) was added, followed by homogenization and incubation at room temperature for 10 minutes. As much as $1 \mathrm{~mL}$ of buffer D (50\% Folin-Ciocalteu dissolved in $\mathrm{H}_{2} \mathrm{O}$ ) was added, homogenized, and incubated at room temperature for 10 minutes. The absorbance of the solution was measured on a spectrophotometer at a wavelength of $500 \mathrm{~nm}$. The total dissolved protein was determined by using a standard curve from bovine serum albumin (BSA). Tissue protein content was determined by dividing the total dissolved protein value by the weight of the sample used, while the percentage was determined by calculating the total weight of protein $(\mathrm{mg})$ per $100 \mathrm{mg}$ of leaf sample.

POD activity was measured based on the Kar and Mishra (1976) protocol. A total of $100 \mu 1$ of protein extract was mixed with $2.5 \mathrm{~mL}$ of pyrogallol $0.2 \mathrm{M}$ and $250 \mathrm{mg}$ of $1 \% \mathrm{H}_{2} \mathrm{O}_{2}$. The absorbance values after the reaction were measured using a spectrophotometer at a wavelength of $420 \mathrm{~nm}$ every 30 seconds for 150 seconds. The blank used was a mixture of the same solution without protein extract, replaced with phosphate buffer. POD activity was calculated as an increase in absorbance value per unit time per protein weight $\left(\Delta_{\mathrm{A} 420} \cdot \mathrm{min}^{-1} \cdot \mathrm{mg}^{-1}\right.$ protein).

\author{
POD activity $=$ \\ difference in absorbance of blank and samples \\ quantity of protein $(\mathrm{mg})$ \\ (4).
}

PAL activity was measured based on Dangcham et al. (2008). Briefly, $0.1 \mathrm{~mL}$ protein extract was combined with $2.4 \mathrm{~mL}$ of L-Phe buffer (0.5 M TrisHCL containing $6 \mu \mathrm{M}$ L-phenylalanine) $\mathrm{pH} 8.5$ and incubated at $37^{\circ} \mathrm{C}$ for 1 hour. The incubation results were then combined with $0.5 \mathrm{~mL}$ of $5 \mathrm{M} \mathrm{HCl}$. The absorbance value of the solution was measured at a wavelength of $290 \mathrm{~nm}$. The blank used was $2.5 \mathrm{~mL}$ of L-Phe solution with $0.5 \mathrm{~mL}$ of $5 \mathrm{M} \mathrm{HCl}$.

PAL activity $=$

difference in absorbance of blank and samples quantity of protein $(\mathrm{mg})$

(5)

SA contents were measured using the modified Tenhaken and Rübel protocol (1997). A total of $1 \mathrm{~g}$ leaf sample was ground using a pestle and mortar while adding $10 \mathrm{~mL}$ methanol and acetone $(1: 1, \mathrm{v}: \mathrm{v})$ buffer. The suspension was then transferred to an Eppendorf tube and centrifuged at 5,000 rpm for 10 minutes. The supernatant was separated from the pellet. The pellet was resuspended in $3 \mathrm{~mL}$ methanol buffer and acetone $(1: 1, \mathrm{v}: \mathrm{v})$ and centrifuged at 5,000 rpm for 10 minutes. The supernatant from this step was mixed with the previous supernatant and vacuum-dried in a freeze dryer. Methanol (5 $\mathrm{mL}$ of $30 \%$ ) was added to the dry residue. The suspension was then centrifuged at 5,000 rpm for 10 minutes. The pellets were discarded, and the resulting supernatant was used for further analysis. The SA contents in sample plants were analyzed qualitatively and quantitatively using HPLC. The mobile phase used was methanol-sodium acetate buffer $50 \mathrm{mM}(30: 70)$ pH 4.5 (methanol and sodium acetate buffer as much as $500 \mathrm{~mL}$ prepared by homogenizing for 10 minutes on a magnetic stirrer) with a flow rate of $0.6 \mathrm{~mL}$ per minute. First, the sample and the solution for the mobile phase were filtered off using a $0.45 \mu \mathrm{m} \mathrm{RC}$ cellulose acetate filter membrane. The Chromatopac used was Shimadzu C-R7A plus. The wavelength used in this analysis was $280 \mathrm{~nm}$, while the column used was a VP-DS Ultrasphere (a UV detector at a wavelength of A 280). The SA retention time is 2.549 . The formula for calculating the SA contents:

\section{SA contents $=$}

$\frac{\text { sample area }}{\text { standard area }} \times$ standard concentration $\times \frac{\text { dilution factor }}{\text { sample weight }}(6)$. 
Lignin contents in infected leaves were evaluated in three samples from three biological repeats of P. amabilis and P.amboinensis at 12 HPI. It was measured following Chesson protocol (Datta 1981). Briefly, $150 \mathrm{ml} \mathrm{H}_{2} \mathrm{O}$ was added to $1 \mathrm{~g}$ of dry sample (a) and then refluxed at $100{ }^{\circ} \mathrm{C}$ in a water bath for 1 hour. The resulting mixture was filtered, and the residue was washed with $300 \mathrm{~mL}$ hot water and then dried in an oven until constant weight (b). As much as $150 \mathrm{~mL}$ of $1 \mathrm{~N} \mathrm{H}_{2} \mathrm{SO}_{4}$ was added to the residue, then refluxed with a water bath for 1 hour at $100{ }^{\circ} \mathrm{C}$. The mixture was filtered and washed to neutral $\mathrm{pH}$ with $300 \mathrm{~mL}$ of hot water and dried (c). Ten milliliters of $72 \% \mathrm{H}_{2} \mathrm{SO}_{4}$ were added to the dry residue, soaked at room temperature for 4 hours. As much as $150 \mathrm{~mL}$ of $1 \mathrm{~N} \mathrm{H}_{2} \mathrm{SO}_{4}$ was added and refluxed in a water bath for 1 hour at $100{ }^{\circ} \mathrm{C}$. The solid was washed with $400 \mathrm{~mL}_{2} \mathrm{O}$, strained, and heated in an oven at a temperature of $105^{\circ} \mathrm{C}$, and the result was weighed (d). Finally, the residue was heated into ash at $600{ }^{\circ} \mathrm{C}$ and weighed (e). The formula for calculating the lignin contents:

$$
\operatorname{Lignin}(\%)=\frac{(\mathrm{d}-\mathrm{e})}{\mathrm{a}} \times 100 \%(7)
$$

a - dry sample weight;

d - dry sample post refluxed and washed weight; $\mathrm{e}$ - final ash weight.

\section{Data analysis}

The experiments were performed three times. The data obtained were analyzed by analysis of variance (ANOVA) using the Statistical Tool for Agricultural Research (STAR) application. If the treatment was found to have a significant effect on the parameter, the data were further tested with the Tukey test at $\mathrm{p}=0.05$.

\section{RESULTS}

\section{Disease assessment and resistance level of four Phalaenopsis species}

The results of the disease assessment of four Phalaenopsis species are presented in Table 1. SRD symptoms first appeared clearly on 6 HPI. The diameters of soft-rot lesions extended with time in all species and were significantly different between the species on 6 and 12 HPI. However, on 18 HPI, there was no significant difference in soft-rot lesion diameter between $P$. schilleriana and $P$. amabilis. The most prominent lesions were found in P. amabilis, followed by $P$. schilleriana, P. pantherina, and then P. amboinensis, respectively. $P$. amabilis had the fastest soft-rot symptom development, from $7.9 \pm 0.4 \mathrm{~mm}$ on $6 \mathrm{HPI}$ to $20.0 \pm 1.5$ on 18 HPI. Conversely, lesions on P. amboinensis developed more slowly from $0.5 \pm 0.1$ on 6 HPI to $1.3 \pm 0.8$ on 18 HPI. From Table 1, we can see that the highest (80\%) disease severity (1) was on P. amabilis on 6 HPI. In contrast, $P$. amboinensis showed the lowest disease severity (7\%) on 6 HPI. On 12 HPI, P. amabilis reached $100 \%$ disease severity, while P.amboinensis, P. pantherina, and P. schilleriana showed $7 \%, 50 \%$, and $93 \%$ disease severity, respectively. The resistance category of each species was determined based on the disease severity as described in the methods section. On 6 HPI, P. amabilis was classified as very susceptible, while $P$. schilleriana was moderately susceptible, and $P$. pantherina was moderately resistant. On 12 HPI, $P$. schilleriana was in the very susceptible category, while $P$. pantherina was moderately susceptible; on $18 \mathrm{HPI}$, they became susceptible and very susceptible, respectively. In contrast, P. amboinensis was in the resistant category from the beginning until the end of the observation. These results showed that P. amabilis is the most susceptible and P.amboinensis is the most resistant species among the four evaluated species.

Table 1. The reaction of four Phalaenopsis species to D. dadantii inoculation

\begin{tabular}{lccccccccc}
\hline \multirow{2}{*}{ Species } & \multicolumn{3}{c}{$6 \mathrm{HPI}$} & \multicolumn{3}{c}{$12 \mathrm{HPI}$} & \multicolumn{3}{c}{$18 \mathrm{HPI}$} \\
\cline { 2 - 10 } & $\begin{array}{c}\text { SrSD } \\
(\mathrm{mm})\end{array}$ & $\begin{array}{c}\mathrm{DS} \\
(\%)\end{array}$ & $\mathrm{RC}$ & $\begin{array}{c}\text { SrSD } \\
(\mathrm{mm})\end{array}$ & $\begin{array}{c}\text { DS } \\
(\%)\end{array}$ & $\mathrm{RC}$ & $\begin{array}{c}\text { SrSD } \\
(\mathrm{mm})\end{array}$ & $\begin{array}{c}\mathrm{DS} \\
(\%)\end{array}$ & RC \\
\hline P. amboinensis & $0.5 \pm 0.1^{\mathrm{d}}$ & $7 \pm 0.0$ & $\mathrm{R}$ & $0.6 \pm 0.5^{\mathrm{d}}$ & $7 \pm 0.1$ & $\mathrm{R}$ & $1.3 \pm 0.8^{\mathrm{c}}$ & $20 \pm 0.1$ & $\mathrm{R}$ \\
P. pantherina & $2.7 \pm 1.3^{\mathrm{c}}$ & $30 \pm 0.1$ & $\mathrm{MR}$ & $4.4 \pm 3.2^{\mathrm{c}}$ & $50 \pm 0.4$ & $\mathrm{MS}$ & $7.9 \pm 7.1^{\mathrm{b}}$ & $70 \pm 0.5$ & $\mathrm{~S}$ \\
P. schilleriana & $4.4 \pm 0.6^{\mathrm{b}}$ & $50 \pm 0.0$ & $\mathrm{MS}$ & $10.1 \pm 2.5^{\mathrm{b}}$ & $93 \pm 0.2$ & $\mathrm{VS}$ & $15.4 \pm 4.7^{\mathrm{a}}$ & $100 \pm 0.2$ & $\mathrm{VS}$ \\
P. amabilis & $7.9 \pm 0.4^{\mathrm{a}}$ & $83 \pm 0.1$ & $\mathrm{VS}$ & $14.3 \pm 1.4^{\mathrm{a}}$ & $100 \pm 0.0$ & $\mathrm{VS}$ & $20.0 \pm 1.5^{\mathrm{a}}$ & $100 \pm 0.0$ & $\mathrm{VS}$ \\
\hline
\end{tabular}

The leaf cuts were inoculated with $D$. dadantii suspension $\left(\mathrm{OD}_{600}=0.2,6 \times 10^{6} \mathrm{CFU}\right)$ and incubated in covered plastic boxes with a base of wet tissue paper (humidity of 75\%). The soft-rot symptom diameter was measured at 6 to 18 hours post-inoculation (HPI). The number within a column followed by the same letter means non-significantly different at Tukey test $(\mathrm{p}=0.05)$. SrSD soft-rot symptom diameter, DS - disease severity, and RC - resistant class ( $\mathrm{R}$ - resistant, $\mathrm{MR}$ - moderate resistant, MS - moderate, $\mathrm{S}$ - susceptible, VS - very susceptible) 
The soft-rot disease symptoms of the four species are shown in Figure 1A. The symptoms are characterized by necrosis, brownishness, rottenness, and wet areas around the infection site. Figure 1A also provides an average colony-forming unit (CFU) value from each inoculated leaf of the species on $18 \mathrm{HPI}$. The highest number of CFU $\left(2 \times 10^{6}\right)$ were found in P.amabilis, followed by P. schilleriana $\left(1 \times 10^{6}\right)$, P. pantherina $\left(3 \times 10^{5}\right)$, and $P$. amboinensis $\left(5 \times 10^{4}\right)$, respectively. This data revealed the trend of CFU among the species. The species with the heaviest soft-rot symptoms (P. amabilis) had a more significant number of CFU than the species with the slightest soft-rot symptoms (P. amboinensis), which means a higher number of bacterial cells in the infected leaves of $P$. amabilis than $P$. amboinensis. A higher $\mathrm{CFU}$ value seemed to correlate with broader SRD symptoms in susceptible species (Table 1), showing that the pathogen successfully broke the host cell wall as the physical barrier. Besides the CFU value, Figure $1 \mathrm{~B}$ also shows the area under the disease progress curve (AUPDC). The highest position of AUPDC is from $P$. amabilis, and the lowest position is from $P$. amboinensis. The rapid increase of AUPDC happened on 6 to $12 \mathrm{HPI}$, as shown by P. amabilis, P. pantherina, and $P$. schilleriana. In contrast, there was no significant increase in AUPDC on P. amboinensis. Soft-rot disease symptoms, disease severity, $\mathrm{CFU}$, and AUPDC values suggest different levels of resistance in the four species and $P$. amboinensis and $P$. amabilis as being very distinct in their response to $D$. dadantii infection.

\section{POD, PAL, SA, and lignin content in four Phalaenopsis species}

We performed quick screening for POD and PAL activities of these four species by using mixed samples of three biological repeats of infected leaves from each species on 12 and 16 HPI. The results showed that POD activities of P.amboinensis, P. pantherina, $P$. schilleriana were $2.0 \times 10^{-4}$, $0.77 \times 10^{-4}, \quad 7.25 \times 10^{-4} \mathrm{u} \cdot \mathrm{min}^{-1} \cdot \mathrm{mg}^{-1}$ protein on $12 \mathrm{HPI}$, respectively, while those of $P$. amabilis was $8.73 \times 10^{-4} \mathrm{u} \cdot \mathrm{min}^{-1} \cdot \mathrm{mg}^{-1}$ protein. On 16 HPI, POD activities of $P$.amboinensis, $P$. pantherina, and $P$. schilleriana were $1.14 \times 10^{-4}, 0.57 \times 10^{-4}$, and
$4.74 \times 10^{-4} \mathrm{u} \cdot \mathrm{min}^{-1} \cdot \mathrm{mg}^{-1}$ protein. In contrast, $P$. amabilis POD activities increased sharply to $72.49 \times 10^{-4} \mathrm{u} \cdot \mathrm{min}^{-1} \cdot \mathrm{mg}^{-1}$ protein. PAL activities in $P$. amboinensis, $P$. pantherina, and $P$. schilleriana on 12 HPI were $1.20 \times 10^{-4}, 0.95 \times 10^{-4}$, and $13.75 \times 10^{-4} \mathrm{u} \cdot \mathrm{min}^{-1} \cdot \mathrm{mg}^{-1}$ protein, while in $P$. amabilis, they were $13.41 \times 10^{-4} \mathrm{u} \cdot \mathrm{min}^{-1} \cdot \mathrm{mg}^{-1}$ protein. On 16 HPI, PAL activities in P.amboinensis, P. pantherina, and $P$. schilleriana were $1.82 \times 10^{-4}$, $1.11 \times 10^{-4}$, and $14.73 \times 10^{-4} \mathrm{u} \cdot \mathrm{min}^{-1} \cdot \mathrm{mg}^{-1}$ protein; conversely, in P.amabilis, they increased to $123.51 \mathrm{u} \cdot \mathrm{min}^{-1} \cdot \mathrm{mg}^{-1}$ protein.

Interestingly, POD and PAL activities were the highest in the very susceptible species ( $P$. amabilis), increasing around nine-fold from 12 to 16 HPI. In contrast, the resistant species, P. amboinensis, showed much lower POD and PAL activities. The higher increase in POD and PAL activities in P. amabilis at 16 HPI suggested it is induced by $D$. $d a$ dantii infection. For more detailed observation of POD and PAL activities, we selected the two extreme species for their resistance to $D$. dadantii (P. amabilis vs. P. amboinensis) and observed the POD and PAL activities on $12 \mathrm{HPI}$ and compared to the non-inoculated and inoculated leaves. We chose $P$. amabilis, not $P$. schilleriana because, from the quick screening, P. amabilis had extreme POD and PAL, even though both are included in the very susceptible class to $D$. dadantii.

As shown in Table 2, POD and PAL activities in P.amabilis and P.amboinensis had a pattern similar to the previous results from the screening of four species. POD and PAL activities in P. amabilis (very susceptible) were significantly higher than those in P. amboinensis (resistant). SA contents from P. amabilis and P. amboinensis are also presented in Table 2. The data shows that P. amabilis, the very susceptible species, had twice lower SA content than $P$. amboinensis, the resistant species. However, there is no significant difference in the SA contents between inoculated and uninoculated leaves in each species. Similar SA content level indicated that SA did not increase from 0 to $12 \mathrm{HPI}$. Lignin contents measured in the infected leaves of P. amboinensis and P. amabilis at 12 HPI showed no significant difference between the two species (Figure 2). 


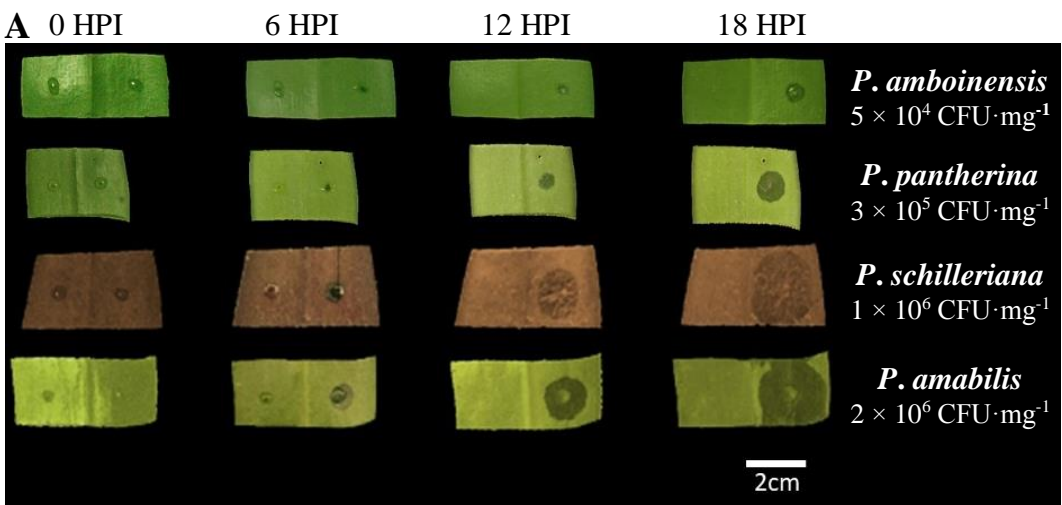

\section{$\mathbf{B}$}

Area under the disease progress curve

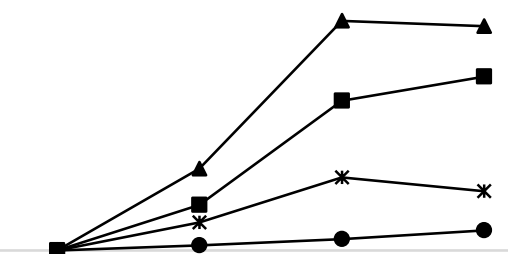

0HPI 6 HPI 12 HPI 18 HPI

$\rightarrow-P$. amboinensis $\rightarrow$ * P. pantherina

$\longrightarrow$ P. schilleriana $\longrightarrow$ P. amabilis

Figure 1. The development of soft-rot disease symptoms among four species: (A) SrSD on infected leaves at 018 hours post-inoculation (HPI), D. dadantii colony-forming units (CFU) in infected leaves at 18 HPI, (B) the area under disease progress curve in four Phalaenopsis species at various HPI

Table 2. POD, PAL, and SA content in P. amabilis and P. amboinensis 12 hours post-inoculation

\begin{tabular}{llccc}
\hline $\begin{array}{l}\text { Resistance } \\
\text { level to } \\
\text { D. dadantii }\end{array}$ & \multicolumn{1}{c}{ Treatment } & $\begin{array}{c}\text { POD } \\
\left(\text { unit } \cdot \mathrm{min}^{-1} \cdot \mathrm{mg}^{-1} \text { protein } \times 10^{-4}\right)\end{array}$ & $\begin{array}{c}\text { PAL } \\
\left(\text { unit } \cdot \mathrm{min}^{-1} \cdot \mathrm{mg}^{-1} \text { protein } \times 10^{-4}\right)\end{array}$ & $\begin{array}{c}\text { SA } \\
(\mathrm{ppm} \text { of fresh sample) }\end{array}$ \\
\hline $\begin{array}{l}\text { very } \\
\text { susceptible }\end{array}$ & P. amabilis non-inoculated & $15.30 \pm 6.93^{\mathrm{a}}$ & $12.20 \pm 1.60^{\mathrm{a}}$ & $5.26 \pm 0.22^{\mathrm{a}}$ \\
& P. amabilis inoculated & $14.96 \pm 11.78^{\mathrm{a}}$ & $10.78 \pm 7.59^{\mathrm{a}}$ & $5.32 \pm 0.46^{\mathrm{a}}$ \\
\hline & P. amboinensis non-inoculated & $2.35 \pm 0.22^{\mathrm{b}}$ & $1.54 \pm 0.16^{\mathrm{b}}$ & $12.56 \pm 2.83^{\mathrm{b}}$ \\
& P. amboinensis inoculated & $1.64 \pm 0.83^{\mathrm{b}}$ & $1.26 \pm 0.44^{\mathrm{b}}$ & $12.88 \pm 2.14^{\mathrm{b}}$ \\
\hline
\end{tabular}

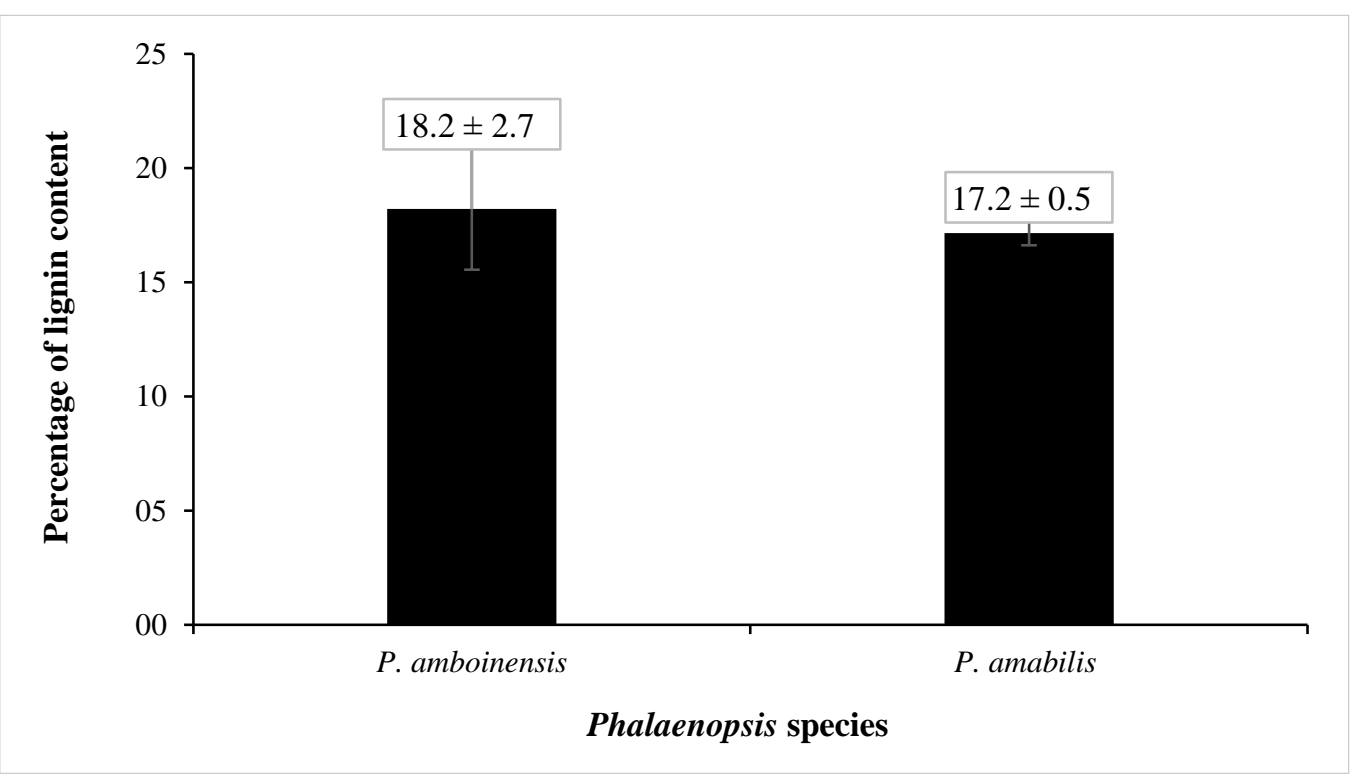

Figure 2. Percentage of lignin content in dry weight of Phalaenopsis species resistant (P. amboinensis) and very susceptible ( $P$. amabilis) of $D$. dadantii at 12 HPI. There is no significant difference between the two species based on the Student's T-test 


\section{DISCUSSION}

Soft-rot disease (SRD) is a very devastating disease in the production of essential crops such as potato (Lojkowska \& Kelman 1994; Pérombelon 2002; Motyka et al. 2017; Rossmann et al. 2018), Aloe vera (Pervez et al. 2016), cucumber (Meng et al. 2017), carrot (Chandrashekar et al. 2018), pineapple (Aeny et al. 2020), Chinese cabbage (Liu et al. 2019b), chicory, Arabidopsis, tomato, green pepper, red pepper (Reverchon \& Nasser 2013), calla lily (Luzzatto et al. 2007), Phalaenopsis (Sudarsono et al. 2018) and other horticulture and plants from seedling to maturity and postharvest. In Phalaenopsis, different species showed different resistant responses post- $D$. dadantii inoculation. The species resistant class order in this study was similar to Sukma et al. (2017). P. amboinensis was the most resistant species compared to $P$. pantherina, $P$. schilleriana, and $P$. amabilis.

SRD is caused by Pectobacterium and Dickeya genera, gram-negative necrotrophic phytopathogens (Agyemang et al. 2020). Necrotrophic pathogens acquire nutrients for growth and reproduction from dead cells (Mengiste 2012). Both of the genera can secrete plant cell wall degrading enzymes such as pectinase, polygalacturonase, protease, and cellulase that degrade the host cell wall, macerating host tissue, killing the host cells, and causing wetness and often an unpleasant odor from rotten host tissue that releases nutrients for bacterial growth (Toth et al. 2003; Charkowski 2018). P. amboinensis may inhibit the bacterial cell multiplication or control the activities of cell wall degradation enzymes resulting in minimized cell death and giving disadvantages for bacterial growth.

Necrotrophic pathogens manipulate the ROSmediated defense response of plants to facilitate cell death. ROS accumulation is also a virulence factor for disease development in necrotrophs such as B. cinerea (Asai et al. 2010) and Alternaria solani (Kobayashi et al. 2012). The effector released by the pathogen using type II and III secretion systems induces a high level of ROS accumulation, known as an oxidative burst, leading to hypersensitive-programmed cell death (HR-PCD) of the host plant (Dey et al. 2020; Expert et al. 2018).
ROS can severely damage carbohydrates, proteins, lipids, and DNA due to the highly reactive nature of the host and the pathogen (Hasanuzzaman et al. 2020). Interestingly, the study of necrotrophic pathogens showed that D.dadantii could survive in an environment with high ROS levels; the pathogen can secrete iron-binding protein that reduces the toxicity of $\mathrm{H}_{2} \mathrm{O}_{2}$ possibly by preventing the Fenton reaction (Liu et al. 2019a). We did not measure the ROS content in our study; however, we predict that P. amboinensis (resistant species) has a low ROS content, which is consisted with low POD activity. In contrast, P. amabilis (very susceptible species) may be high in ROS, which promotes POD activities; however, it cannot help the plant cell to survive $D$. dadantii infection because $D$. dadantii can control the ROS effect.

ROS accumulation could be predicted by the activities of antioxidant enzymes, POD and PAL. However, in the present results, there is no significant difference in POD and PAL activities between the non-inoculated and inoculated leaves in each species, suggesting that pathogen inoculation did not induce POD and PAL activities at 12 HPI. This result is different from the quick screening, where POD and PAL increased in P. amabilis at 16 HPI. The data revealed the high POD and PAL activities in a very susceptible species that are different from those previously reported; for example, POD and PAL showed higher activities and gene expression in resistant than susceptible genotypes in tobacco against Meloidogyne incognita (Li et al. 2018) and tomato against Ralstonia solanacearum (Jayanna \& Umesha 2017). A similar trend in 12 HPI was also found on $16 \mathrm{HPI}$; interestingly, a high increase in POD and PAL activity from 12 to 16 HPI was found only in P. amabilis. Fu et al. (2012) found that POD was more dynamic in $P$. amabilis inoculated with $E$. chrysanthemi compared to the control, indicating the ROS and enzymatic antioxidant systems (as the ROS scavenger) were involved in the response of the Phalaenopsis to the pathogen infection. Higher POD activity in susceptible pear cultivar was also found on 1-day post-infection by necrotrophic pathogen E. amylovora (Honty et al. 2008). 
Other research showed low PAL activities, total phenolics, total flavonoid, and total tannin in resistant Zingiber species compared to susceptible cultivar against necrotrophic Pythium myriotylum, indicating lower effectiveness of phenolics in the species, and the resistance may be controlled by single class of metabolites (Ganapathy et al. 2016). The initial stage of the necrotrophic phase was also found associated with high ROS and antioxidant activity in sesame plants against Macrophomina phaseolina (Chowdhury et al. 2017). Our results can suggest that the $D$. dadantii successfully targeted ROS mechanisms in susceptible Phalaenopsis species (characterized by high POD) to provide plant cell death and adopt the infection environment for their own survival and multiplication.

Both POD and PAL are inducible enzymes that react under stress (Fu et al. 2012; Prasannath 2017; Tsers et al. 2020). Besides the scavenging role, both POD and PAL are also involved in lignin biosynthesis (Xu et al. 2011; Liu et al. 2018). Lignin facilitates the host cell wall's physical barrier and prevents the pathogen infection by spatial restriction, which is disturbed by defects in lignin deposition, trapping pathogens and thereby terminating their growth (Lee et al. 2019). However, there was no difference in lignin contents between the two species with distinctly differing resistance levels to $D$. $d a$ dantii. All of those suggest that lignin contents may not contribute to the physical resistance mechanism to $D$. dadantii in resistant species ( $P$. amboinensis).

The resistance mechanism in $P$. amboinensis may be caused by the higher SA contents in these plants. ROS, POD, and PAL are known to be synergic to SA (Herrera-Vásquez et al. 2015; Kumari \& Vengadaramana 2017). However, in our present results, POD, PAL, and SA showed a contrasting pattern in P. amboinensis. According to Durner and Klessig (1995), SA or SA-analog can inhibit the activity of ascorbate peroxidase (APX), an enzyme scavenging $\mathrm{H}_{2} \mathrm{O}_{2}$, and induce defense-related genes, responsible for increasing the resistance to tobacco mosaic virus. It remains unclear whether SA in $P$. amboinensis also inhibits POD activities.
PAL is the first enzyme reported in SA biosynthesis (Huang et al. 2010), but lower PAL and higher SA were found in resistant P. amboinensis, contrasting with the very susceptible species $P$. amabilis. From these results, we predict that high SA contents in resistant species may be synthesized through the isochorismate pathway instead of the PAL pathway. Higher SA in the resistant species may be associated with the ICS1 gene responsible for the production of $\sim 90 \%$ defense-related SA, while the PAL pathway produced $\sim 10 \%$ of SA in $A r$ abidopsis (Garcion et al. 2008). The role of SA in the mechanism of resistance to the necrotrophic pathogen $D$. dadantii is not fully understood. Some reports suggest a positive effect of SA on Phalaenopsis resistance to D. dadantii. Exogenous SA application in vitro and in vivo slightly induced $P$. amabilis resistance to $D$. dadantii (Lubis et al. 2020; Sanjaya et al. 2020). Further research is needed to better understand the mechanism of $P$. amboinensis resistance to D. dadantii and the role of SA.

\section{CONCLUSION}

$P$. amboinensis is more resistant than $P$. pantherina, $P$. schilleriana, and $P$. amabilis to $D$. $d a$ dantii. The high activity of POD and PAL in P. amabilis (very susceptible species) under $D$. dadantii infection suggests that the activity of POD and PAL may not be effective in defense against softrot disease, while SA plays an important role in the resistance of $P$. amboinensis to $D$. dadantii. Low PAL activity with a high SA content implies that SA from the isochorismate pathway (not from the PAL-pathway) may be involved in the mechanism of $P$. amboinensis resistance to $D$. dadantii. Therefore, endogenous SA content may be a valuable marker for the detection of resistant genotypes of Phalaenopsis spp.

\section{Acknowledgments}

The authors thank the Indonesian Ministry of Research and Technology for funding this research as part of the 2019 "Pendidikan Magister menuju Doktor untuk Sarjana Unggul" (PMDSU) coordinated by Dewi Sukma. 


\section{REFERENCES}

Aeny T.N., Suharjo R., Ginting C., Hapsoro D., Niswati A. 2020. Characterization and host range assessment of Dickeya zeae associated with pineapple soft rot disease in East Lampung, Indonesia. Biodiversitas 21(2): 587-595. DOI: 10.13057/biodiv/d210221.

Agyemang P.A., Kabir M.N., Kersey C.M., Dumenyo C.K. 2020. The bacterial soft rot pathogens, Pectobacterium carotovorum and $P$. atrosepticum, respond to different classes of virulence-inducing host chemical signals. Horticulturae 6(1); 13; 13 p. DOI: 10.3390/horticulturae6010013.

Andersen E.J., Ali S., Byamukama E., Yen Y., Nepal M.P. 2018. Disease resistance mechanisms in plants. Genes 9(7); 339; 30 p. DOI: 10.3390/genes9070339.

Asai S., Mase K., Yoshioka H. 2010. Role of nitric oxide and reactive oxygen species in disease resistance to necrotrophic pathogens. Plant Signaling and Behavior 5(7): 872-874. DOI: 10.4161/psb.5.7.11899.

Bhuiyan N.H., Selvaraj G., Wei Y., King J. 2009. Role of lignification in plant defense. Plant Signaling and Behavior 4(2): 158-159. DOI: 10.4161/psb.4.2.7688.

Bindschedler L.V., Dewdney J., Blee K.A., Stone J.M., Asai T., Plotnikov J. et al. 2006. Peroxidase-dependent apoplastic oxidative burst in Arabidopsis required for pathogen resistance. Plant Journal 47(6): 851863. DOI: 10.1111/j.1365-313x.2006.02837.x.

Bolwell G.P., Wojtaszek P. 1997. Mechanisms for the generation of reactive oxygen species in plant defense - a broad perspective. Physiological and Molecular Plant Pathology 51(6): 347-366. DOI: 10.1006/pmpp.1997.0129.

Chandrashekar B.S., Prasannakumar M.K., Puneeth M.E., Teli K., Priyanka K., Mahesh H.B., Desai R.U. 2018. First report of bacterial soft rot of carrot caused by Klebsiella variicola in India. New Disease Reports 37(1): 21. DOI: 10.5197/j.2044-0588.2018.037.021.

Charkowski A.O. 2018. The changing face of bacterial soft-rot diseases. Annual Review of Phytopathology 56(1): 269-288. DOI: 10.1146/annurev-phyto-080417-045906.

Chowdhury S., Basu A., Kundu S. 2017. Biotrophynecrotrophy switch in pathogen evoke differential response in resistant and susceptible sesame involving multiple signaling pathways at different phases.
Scientific Reports 7(1); 17251; 17 p. DOI: 10.1038/s41598-017-17248-7.

Czajkowski R., Pérombelon M.C.M., van Veen J.A., van der Wolf J.M. 2011. Control of blackleg and tuber soft rot of potato caused by Pectobacterium and Dickeya species: a review. Plant Pathology 60(6): 999-1013. DOI: 10.1111/j.1365-3059.2011.02470.x.

Dangcham S., Bowen J., Ferguson I.B., Ketsa S. 2008. Effect of temperature and low oxygen on pericarp hardening of mangosteen fruit stored at low temperature. Postharvest Biology and Technology 50(1): 37-44. DOI: 10.1016/j.postharvbio.2008.02.005.

Datta R. 1981. Acidogenic fermentation of lignocellulose - acid yield and conversion of components. Biotechnology and Bioengineering 23(9): 2167-2170. DOI: 10.1002/bit.260230921.

Davidsson P.R., Kariola T., Niemi O., Palva E.T. 2013. Pathogenicity of and plant immunity to soft rot pectobacteria. Frontiers in Plant Science 4; 191; 13 p. DOI: 10.3389/fpls.2013.00191.

Dey N., Roy U.K., Aditya M., Bhattacharjee S. 2020. Defensive strategies of ROS in Programmed Cell Death associated with hypertensive response in plant pathogenesis. Annals of Systems Biology 3(1): 1-9. DOI: 10.17352/asb.000004.

Durner J., Klessig D.F. 1995. Inhibition of ascorbate peroxidase by salicylic acid and 2,6-dichloroisonicotinic acid, two inducers of plant defense responses. Proceedings of the National Academy of Sciences 92(24): 11312-11316. DOI: 10.1073/pnas.92.24.11312.

Expert D., Patrit O., Shevchik V.E., Perino C., Boucher V., Creze C. et al. 2018. Dickeya dadantii pectic enzymes necessary for virulence are also responsible for activation of the Arabidopsis thaliana innate immune system. Molecular Plant Pathology 19(2): 313-327. DOI: 10.1111/mpp.12522.

Fatima U., Senthil-Kumar M. 2015. Plant and pathogen nutrient acquisition strategies. Frontiers in Plant Science 6; 750; 12 p. DOI: 10.3389/fpls.2015.00750.

Freeman B.C., Beattie G.A. 2009. Bacterial growth restriction during host resistance to Pseudomonas syringae is associated with leaf water loss and localized cessation of vascular activity in Arabidopsis thaliana. Molecular Plant-Microbe Interactions 22(7): 857-867. DOI: 10.1094/mpmi-22-7-0857. 
Fu S.-F., Tsai T.-M., Chen Y.-R., Liu C.-P., Haiso L.-J., Syue L.-H. et al. 2012. Characterization of the early response of the orchid, Phalaenopsis amabilis, to Erwinia chrysanthemi infection using expression profiling. Physiologia Plantarum 145(3): 406-425. DOI: 10.1111/j.1399-3054.2012.01582.x.

Ganapathy G., Keerthi D., Nair R.A., Pillai P. 2016. Correlation of phenylalanine ammonia lyase (PAL) and tyrosine ammonia lyase (TAL) activities to phenolics and curcuminoid content in ginger and its wild congener, Zingiber zerumbet following Pythium myriotylum infection. European Journal of Plant Pathology 145(4): 777-785. DOI: 10.1007/s10658-016-0865-2.

Garcion C., Lohmann A., Lamodière E., Catinot J., Buchala A., Doermann P., Mètraux J.-P. 2008. Characterization and biological function of the ISOCHORISMATE SYNTHASE2 gene of Arabidopsis. Plant Physiology 147(3): 1279-1287. DOI: 10.1104/pp.108.119420.

Gechev T.S., Van Breusegem F., Stone J.M., Denev I., Laloi C. 2006. Reactive oxygen species as signals that modulate plant stress responses and programmed cell death. BioEssays 28(11): 1091-1101. DOI: 10.1002/bies.20493.

Gill S.S., Tuteja N. 2010. Reactive oxygen species and antioxidant machinery in abiotic stress tolerance in crop plants. Plant Physiology and Biochemistry 48(12): 909-930. DOI: 10.1016/j.plaphy.2010.08.016.

Giorgio M., Trinei M., Migliaccio E., Pelicci P.G. 2007. Hydrogen peroxide: a metabolic by-product or a common mediator of ageing signals? Nature Reviews Molecular Cell Biology 8(9): 722-728. DOI: 10.1038/nrm2240.

Golubenko Z., Akhunov A., Khashimova N., Beresneva Y., Mustakimova E., Ibragimov F., Abdurashidova N., Stipanovic R. 2007. Induction of peroxidase as a disease resistance response in resistant (Hibiscus trionum) and susceptible (Althea armeniaca) species in the family Malvaceae. Phytoparasitica 35(4): 401-413. DOI: 10.1007/bf02980704.

Göhre V., Robatzek S. 2008. Breaking the barriers: Microbial effector molecules subvert plant immunity. Annual Review of Phytopathology 46: 189-215. DOI: 10.1146/annurev.phyto.46.120407.110050.

Hanudin, Suhardi 2009. Praevaluasi karakter ketahanan terhadap penyakit busuk lunak pada anggrek Phalaenopsis. Laporan Hasil Penelitian Balai Penelitian Tanaman Hias, Segunung, Indonesia, 14 p. [in Indonesian]
Hasanuzzaman M., Bhuyan M.H.M.B., Zulfiqar F., Raza A., Mohsin S.M., Al Mahmud J. et al. 2020. Reactive oxygen species and antioxidant defense in plants under abiotic stress: Revisiting the crucial role of a universal defense regulator. Antioxidants 9(8); 681; 52 p. DOI: 10.3390/antiox9080681.

Herrera-Vásquez A., Salinas P., Holuigue L. 2015. Salicylic acid and reactive oxygen species interplay in the transcriptional control of defense genes expression. Frontiers in Plant Science 6; 171; 9. DOI: 10.3389/fpls.2015.00171.

Honty K., Hevesi M., Tóth M., Sárdi É., StefanovitsBányai É. 2008. Effect of Erwinia amylovora infection in biochemical changes of different pear fruits. Acta Horticulturae 800: 879-884. DOI: 10.17660/actahortic.2008.800.119.

Huang J., Gu M., Lai Z., Fan B., Shi K., Zhou Y.-H. et al. 2010. Functional analysis of the Arabidopsis $P A L$ gene family in plant growth, development, and response to environmental stress. Plant Physiology 153(4): 1526-1538. DOI: 10.1104/pp.110.157370.

Huang H., Ullah F., Zhou D.-X., Yi M., Zhao Y. 2019. Mechanisms of ROS regulation of plant development and stress responses. Frontiers in Plant Science $10 ; 800 ; 10$ p. DOI: 10.3389/fpls.2019.00800.

Huang S., Zhang X., Fernando W.G.D. 2020. Directing trophic divergence in plant-pathogen interactions: Antagonistic phytohormones with NO doubt? Frontiers in Plant Science 11; 600063; 9 p. DOI: 10.3389/fpls.2020.600063.

Kumari Y.S.M.A.I., Vengadaramana A. 2017. Stimulation of defense enzymes in tomato (Solanum lycopersicum L.) and chilli (Capsicum annuum L.) in response to exogenous application of different chemical elicitors. Universal Journal of Plant Science 5(1): 10-15. DOI: 10.13189/ujps.2017.050102.

Jayanna S.K., Umesha S. 2017. Enhancement of the expression of defense genes in tomato against Ralstonia solanacearum by N-octanoyl-L-homoserine lactone. African Journal of Microbiology Research 11(5): 194-203. DOI: 10.5897/ajmr2016.8370.

Kapoor D., Singh S., Kumar V., Romero R., Prasad R., Singh J. 2019. Antioxidant enzymes regulation in plants in reference to reactive oxygen species (ROS) and reactive nitrogen species (RNS). Plant Gene 19; 100182; 13 p. DOI: 10.1016/j.plgene.2019.100182. 
Kar M., Mishra D. 1976. Catalase, peroxidase, and polyphenoloxidase activities during rice leaf senescence. Plant Physiology 57(2): 315-319. DOI: 10.1104/pp.57.2.315.

Kobayashi M., Yoshioka M., Asai S., Nomura H., Kuchimura K., Mori H. et al. 2012. StCDPK5 confers resistance to late blight pathogen but increases susceptibility to early blight pathogen in potato via reactive oxygen species burst. New Phytologist 196(1): 223-237. DOI: 10.1111/j.1469-8137.2012.04226.x.

Lee M-H., Jeon H.S., Kim S.H., Chung J.H., Roppolo D., Lee H.-J. et al. 2019. Lignin-based barrier restricts pathogens to the infection site and confers resistance in plants. EMBO Journal 38(23); e101948; 17 p. DOI: 10.15252/embj.2019101948.

Lefevere H., Bauters L., Gheysen G. 2020. Salicylic acid biosynthesis in plants. Frontiers in Plant Science 11; 338; 7 p. DOI: 10.3389/fpls.2020.00338.

Li X., Xing X., Tian P., Zhang M., Huo Z., Zhao K. et al. 2018. Comparative transcriptome profiling reveals defense-related genes against Meloidogyne incognita invasion in tobacco. Molecules 23(8); 2081; 16 p. DOI: $10.3390 /$ molecules 23082081.

Liu Q., Luo L., Zheng L. 2018. Lignins: Biosynthesis and biological functions in plants. International Journal of Molecular Sciences 19(2); 335; 16 p. DOI: 10.3390/ijms19020335.

Liu L., Gueguen-Chaignon V., Gonçalves I.R., Rascle C., Rigault M., Dellagi A. et al. 2019a. A secreted metal-binding protein protects necrotrophic phytopathogens from reactive oxygen species. Nature Communications $10 ; 4853 ; 15$ p. DOI: 10.1038/s41467-019-12826-X.

Liu M., Wu F., Wang S., Lu Y., Chen X., Wang Y. et al. 2019b. Comparative transcriptome analysis reveals defense responses against soft rot in Chinese cabbage. Horticulture Research 6; 68; 18 p. DOI: 10.1038/s41438-019-0149-z.

Lowry O.H., Rosebrough N.J., Farr A.L., Randall R.J. 1951. Protein measurement with the Folin phenol reagent. Journal of Biological Chemistry 193(1): 265-275. DOI: 10.1016/s0021-9258(19)52451-6.

Lubis U.N.Q., Sukma D., Sudarsono 2020. Response of in vitro plantlets and induced resistance of Phalaenopsis amabilis seedling to Dickeya dadantii using salicylic acid. Jurnal Agronomi Indonesia 48(3): 331-338. DOI: 10.24831/jai.v48i3.32014. [in Indonesian with English abstract]

Luna E., Pastor V., Robert J., Flors V., Mauch-Mani B., Ton J. 2011. Callose deposition: A multifaceted plant defense response. Molecular Plant-Microbe Interactions 24(2): 183-193. DOI: 10.1094/mpmi-07-10-0149.

Luzzatto T., Yishay M., Lipsky A., Ion A., Belausov E., Yedidia I. 2007. Efficient, long-lasting resistance against the soft rot bacterium Pectobacterium carotovorum in calla lily provided by the plant activator methyl jasmonate. Plant Pathology 56(4): 692701. DOI: 10.1111/j.1365-3059.2007.01622.x.

Łojkowska E., Hołubowska M. 1992. The role of polyphenol oxidase and peroxidase in potato tuber resistance to soft rot caused by Erwinia carotovora. Journal of Phytopathology 136(4): 319-328. DOI: 10.1111/j.1439-0434.1992.tb01314.x.

Łojkowska E., Kelman A. 1994. Comparison of the effectiveness of different methods of screening for bacterial soft rot resistance of potato tubers. American Potato Journal 71: 99-113. DOI: 10.1007/bf02849113.

Meng X., Chai A., Shi Y., Xie X., Ma Z., Li B. 2017. Emergence of bacterial soft rot in cucumber caused by Pectobacterium carotovorum subsp. brasiliense in China. Plant Disease 101(2): 279-287. DOI: 10.1094/pdis-05-16-0763-re.

Mengiste T. 2012. Plant immunity to necrotrophs. Annual Review of Phytopathology 50: 267-294. DOI: 10.1146/annurev-phyto-081211-172955.

Mithöfer A., Maffei M.E. 2017. General mechanisms of plant defense and plant toxins. Plant Toxins, pp. 3-24. DOI: 10.1007/978-94-007-6464-4_21.

Mittler R. 2017. ROS are good. Trends in Plant Science 22(1): 11-19. DOI: 10.1016/j.tplants.2016.08.002.

Motyka A., Zoledowska S., Sledz W., Lojkowska E. 2017. Molecular methods as tools to control plant diseases caused by Dickeya and Pectobacterium spp: A minireview. New Biotechnology 39: 181-189. DOI: 10.1016/j.nbt.2017.08.010. 
Pervez Z., Alam M.S., Islam M.S. 2016. First report of bacterial soft rot of Aloe vera (Aloe barbadensis) caused by Pectobacterium chrysanthemi in Bangladesh. Journal of Plant Pathology and Microbiology 7(12); e110. DOI: 10.4172/2157-7471.1000e110.

Pérombelon M.C.M. 1992. Potato blackleg: Epidemiology, host-pathogen interaction and control. Netherlands Journal of Plant Pathology 98: 135-146. DOI: 10.1007/bf01974480.

Pérombelon M.C.M. 2002. Potato diseases caused by soft rot erwinias: an overview of pathogenesis. Plant Pathology 51(1): 1-12. DOI 10.1046/j.0032-0862.2001.shorttitle.doc.x.

Potrykus M., Hugouvieux-Cotte-Pattat N., Lojkowska E. 2018. Interplay of classic Exp and specific Vfm quorum sensing systems on the phenotypic features of Dickeya solani strains exhibiting different virulence levels. Molecular Plant Pathology 19(5): 1238-1251. DOI: 10.1111/mpp.12614.

Prasannath K. 2017. Plant defense-related enzymes against pathogens: A review. AGRIEAST 11(1): 38-48. DOI: 10.4038/agrieast.v11i1.33.

Putri H.A., Purwito A., Sudarsono, Sukma D. 2021. Morphological, molecular and resistance responses to soft-rot disease variability among plantlets of Phalaenopsis amabilis regenerated from irradiated protocorms. Biodiversitas 22(3): 1077-1090. DOI: 10.13057/biodiv/d220301

Reverchon S., Nasser W. 2013. Dickeya ecology, environment sensing and regulation of virulence programme. Environmental Microbiology Reports 5(5): 622-636. DOI: 10.1111/1758-2229.12073.

Rossmann S., Dees M.W., Perminow J., Meadow R., Brurberg M.B. 2018. Soft rot Enterobacteriaceae are carried by a large range of insect species in potato fields. Applied and Environmental Microbiology 84(12); e00281-18. DOI: 10.1128/aem.00281-18.

Sanjaya I P.W., Sukma D., Sudarsono, Chan M.-T. 2020. Effect of genotype, concentration and timing of salicylic acid application to Phalaenopsis against Dickeya dadantii infection. Biodiversitas 21(9): 4317-4324. DOI: 10.13057/biodiv/d210950.
Schippers J.H.M., Foyer C.H., van Dongen J.T. 2016. Redox regulation in shoot growth, SAM maintenance and flowering. Current Opinion in Plant Biology 29: 121-128. DOI: 10.1016/j.pbi.2015.11.009.

Simons T.J., Ross A.F. 1971. Metabolic changes associated with systemic induced resistance to tobacco mosaic virus in Samsun NN tobacco. Phytopathology 61: 293-300. DOI: 10.1094/phyto-61-293.

Singh Y., Nair A.M., Verma P.K. 2021. Surviving the odds: From perception to survival of fungal phytopathogens under host-generated oxidative burst. Plant Communications 2(3); 100142; 17 p. DOI: 10.1016/j.xplc.2021.100142.

Pedras M.S.C., Yaya E.E. 2015. Plant chemical defenses: Are all constitutive antimicrobial metabolites phytoanticipins? Natural Product Communications 10(1): 209-218. DOI: 10.1177/1934578x1501000142.

Sudarsono S., Elina J., Giyanto, Sukma D. 2018. Pathogen causing Phalaenopsis soft rot disease - 16S rDNA and virulence characterisation. Plant Protection Science 54(1): 1-8. DOI: 10.17221/18/2017-pps.

Sukma D., Poerwanto R., Sudarsono, Khumaida N., Artika I M., Wiyono S. 2012. Chitinase and peroxydase activities of crude protein extracts from callus and Trichosanthes cucumerina var. anguina tissues. Jurnal Agronomi Indonesia 40(3): 225-231. [in Indonesian with English abstract]

Sukma D., Elina J., Giyanto, Sudarsono 2017. Disease resistance breeding of Phalaenopsis spp. for tropical environment and molecular marker development for plant selection. Acta Horticulturae 1167: 237-244. DOI: 10.17660/actahortic.2017.1167.36.

Tenhaken R., Rübel C. 1997. Salicylic acid is needed in hypersensitive cell death in soybean but does not act as a catalase inhibitor. Plant Physiology 115(1): 291-298. DOI: 10.1104/pp.115.1.291.

Toth I.K, Bell K.S., Holeva M.C., Birch P.R.J. 2003. Soft rot erwiniae: from genes to genomes. Molecular Plant Pathology 4(1): 17-30.DOI: 10.1046/j.1364-3703.2003.00149.x.

Tsers I., Gorshkov V., Gogoleva N., Parfirova O., Petrova O., Gogolev Y. 2020. Plant soft rot development and regulation from the viewpoint of transcriptomic profiling. Plants 9(9); 1176; 30 p. DOI: 10.3390/plants9091176. 
Walters D., Cowley T., Mitchell A. 2002. Methyl jasmonate alters polyamine metabolism and induces systemic protection against powdery mildew infection in barley seedlings. Journal of Experimental Botany 53(369): 747-756. DOI: 10.1093/jexbot/53.369.747.

Wang S., Wu X.-M., Liu C.-H., Shang J.-Y., Gao F., Guo H.-S. 2020. Verticillium dahliae chromatin remodeling facilitates the DNA damage repair in response to plant ROS stress. PLoS Pathogens 16(4); e1008481; 22 p. DOI: 10.1371/journal.ppat.1008481.

Wang Y., Li X., Fan B., Zhu C., Chen Z. 2021. Regulation and function of defense-related callose deposition in plants. International Journal of Molecular Sciences 22(5); 2393; 15 p. DOI: 10.3390/ijms22052393.

Xu L., Zhu L., Tu L., Liu L., Yuan D., Jin L. et al. 2011. Lignin metabolism has a central role in the resistance of cotton to the wilt fungus Verticillium dahliae as revealed by RNA-Seq-dependent transcriptional analysis and histochemistry. Journal of Experimental Botany 62(15): 5607-5621. DOI: 10.1093/jxb/err245.

Zhang X., Liu C.-J. 2015. Multifaceted regulations of gateway enzyme phenylalanine ammonia-lyase in the biosynthesis of phenylpropanoids. Molecular Plant 8(1): 17-27. DOI: 10.1016/j.molp.2014.11.001. 